\title{
On direct speech and referential perspective in birchbark letters no. 5 from Tver' and no. 286 from Novgorod
}

\section{Прямая речь и референциальная перспектива в берестяных грамотах № 5 из Твери и № 286 из Новгорода}

\author{
Alexey A. Gippius · Jos Schaeken \\ Published online: 22 December 2010 \\ (C) The Author(s) 2010. This article is published with open access at Springerlink.com
}

\begin{abstract}
This article analyses within a pragmaphilological framework the communicative function and linguistic form of birchbark letters no. 5 from Tver' (Tv5) and no. 286 from Novgorod (N286), both dating back to the 14th century. In the case of Tv5, we propose that the letter can best be understood if we assume two instances of direct speech without any markers of reportedness. With regard to N286, we will argue that what seems to be another case of direct speech lacking an introductory verbal tag should in fact be interpreted as an instance of the necessitive use of the imperative.
\end{abstract}

Аннотация Статья посвящена прагмафилологическому анализу двух берестяных грамот XIV в.—№ 5 из Твери и № 286 из Новгорода. В первом случае мы предполагаем, что документ может быть лучше понят при вычленении в нем двух включений прямой речи, вводимой без каких-либо маркеров цитирования. В № 286 фрагмент, который мог бы быть истолкован аналогичным образом, с большей вероятностью трактуется как случай экспрессивного употребления императива в долженствовательном значении.

\section{Introduction}

This paper offers a new interpretation of two birchbark documents- the letter most recently found in Tver', no. 5 (Tv5, where 'Tv' stands für Tver'), and a much-discussed letter from

We are greatly indebted to Daniel E. Collins, The Ohio State University, and Egbert Fortuin, Leiden University, for commenting on earlier drafts of this article. Alexey Gippius' work on this article has been supported by the Russian State Foundation for Humanities (project 09-04-00177a).

\footnotetext{
A. A. Gippius

Institut slavjanovedenija RAN, Moscow, Russia

e-mail: agippius@mail.ru

J. Schaeken ( $\varangle)$

Department of Slavic Languages and Cultures, Leiden University, Leiden, The Netherlands

e-mail: j.schaeken@hum.leidenuniv.nl
} 
Novgorod, no. 286 (N286, where 'N' stands for Novgorod). We will argue that the reading of both texts in the latest edition (DND, 569 and 595f., respectively) does not fully explain the communicative function of the letters and the contexts in which they must have been written. In order to reconstruct a coherent and plausible scenario of what is communicated in Tv5 and N286, we will propose that in both cases part of the letters must have a referential perspective that has not yet been recognized.

The pragmaphilological approach we will take in this investigation is also discussed in Schaeken (this volume). As in Schaeken's article, we will utilize 'function-to-form mapping'. First we will analyze the communicative function of Tv5 and N286 and show that previous reconstructions cannot be brought into line with their linguistic form; we will then propose an alternative scenario of the events and circumstances that are presented by the senders of the letters. As a consequence, this implies a reanalysis of the linguistic form of Tv5 and N286.

\section{Birchbark letter 5 from Tver'}

\subsection{Tver' 5 according to the edition}

Tv5 was found in 1996 during excavations in the city of Tver'. The document $(22.5 \times 3.6 \mathrm{~cm})$ is dated both stratigraphically and extra-stratigraphically to the end of the thirteenth or the beginning of the fourteenth century (DND, 569). Tv5 was first published in 2001 by T. V. Roždestvenskaja (2001, 187-189), and later in a slightly different reading by A. A. Zaliznjak in DND (569) (see Fig. 1).

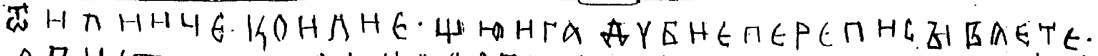
A页H娄

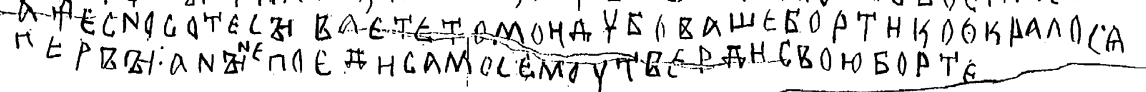

Fig. 1 Drawing of Tv5 (Roždestvenskaja 2001, 186)

Edition according to DND (569), normalized transcription and translation:

1 iw

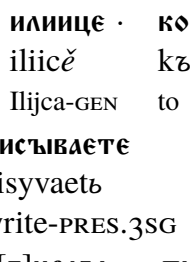

$2 a$

[в]цекъ

a [b]č ely

ти

and bees-ACC.PL

Tu
ti
PTC
no

กA3иก⿻ .

шюига

Аүвие

ot

иกUE .

šjuiga

dubie

переписъваєте

Il'ja-DAT S̆ujga-NoM

oaks-ACC.SG (COLL)

\section{wимaso}

otimaju

no своеи

lazils

gather-PERF.M.SG

АЗ3० АүЕие

take away-PRES.1SG

po svoei

on

POSS.REFL-DAT.SG.F

jazъ dubie

I-NOM oaks-ACC.SG (COLL)

\section{мЕти}

měti

mark-DAT.SG 


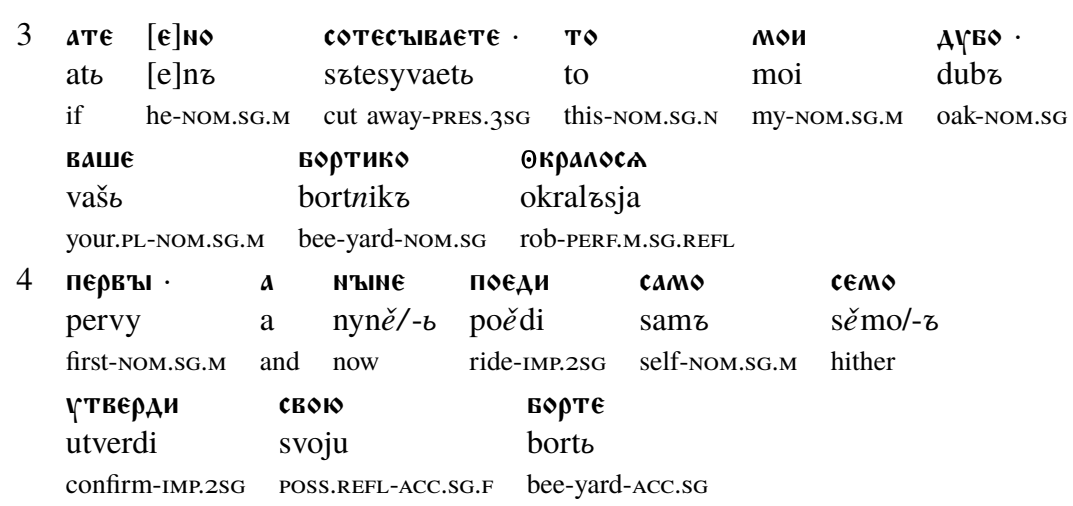

'From Ilijca to Il'ja. Šujga is overwriting [the marks on] the oaks and has taken out the honey from the hives. I am taking away the oaks on my own mark. Let him [even] cut [it] away, it is [still] my oak. Your bee-yard has been robbed first. And now come here yourself; confirm your [ownership of the] bee-yard.'

Lexical notes:

- Dubie perepisyvati (line 1), literally 'overwrite the oaks', refers to the medieval practice of putting marks on bee-trees as a sign of ownership (see Kotkova 1963; Anpilogov 1964, including many drawings of beekeepers' marks; Galton 1971, 23, 43).

- Bčely laziti (2), literally 'gather the bees', is also attested elsewhere in Old Russian with the idiomatic meaning 'take out the honey from the hives' (вынимать мед из ульев, DND, 221, 569). ${ }^{2}$

- The particle $t i$ (2) is used to mark an utterance which the speaker/writer considers to be of specific importance for the hearer/reader to know: 'you should know that Sujga has taken out the honey ...' (see DND, 196f.).

- The word mětb (2) is a hapax in Old Russian. In North Russian dialects it is attested as меть 'mark, sign' (метка, отметка; see DND, 221, 569).

- The word bortb (4) is attested in Old Russian in two established meanings, 'bee-tree'; 'hollow tree in which wild bees are kept' and 'area, forest or lot in the woods with bee-trees' (Sl. XI-XVII vv., 1, 1975, 300). In view of the use of the collective noun dubie 'oaks' $(1,2)$, it is most likely that the second meaning applies to our text. On bortnikz, see the next section.

\subsection{Alternative interpretation of Tv5}

The edition in DND discusses two instances in line 3 where a variant reading of Tv5 had been proposed earlier: First, the letter before $n$ in aTE [E]No is only partially visible: it might be $e$ or $s$. If we are dealing with $s$, the reading a $\mathbf{T E}[\mathbf{c}]$ No-i.e. the conjunction $a$ followed by a noun-might be an alternative. According to V. L. Janin (cf. DND, 569),

\footnotetext{
${ }^{1}$ Russian translation (DND, 569): 'От Илийцы к Илье. Шуйга переделывает метки на дубах и вынимал мед из ульев. Я отбираю дубы по своей метке. Пусть [даже] он стесывает, это [всё равно] мой дуб. Ваша пасека обокрадена первой. Поезжай же теперь сам, утверди [владение] своей бортью.'

${ }^{2}$ There is one other birchbark document which deals with beekeeping; the very fragmentary letter N766 (late 13th-early 14th century) seems to mention the robbery of a bee-yard. The verb vydereti 'pull out' in combination with the noun bčely 'bees' points to a similar action as in Tv5 (cf. Janin and Zaliznjak 2000, 63, with further reference to the beekeeping-laws in the 'Russian Law Code' (Правда Русская) and the use of the same wording as in N766).
} 
tesьno can be interpreted as '(tree) mark, incision' (затёс, зарубка), which, in the opinion of Zaliznjak, would not significantly change the meaning of the sentence: "перевод почти не изменится ('А что затёс он стесывает, так это всё равно мой дуб')” (DND, 569).

Second, the word bortnik子 (obviously written by mistake without $n$ ) can mean not only 'bee-yard', but also 'beekeeper'. The later meaning has been suggested by Roždestvenskaja (2001, 188), who proposes the reading 'Ваш бортник попался на краже первым'. In the edition, this variant is qualified as 'less probable' (“менее вероятным”, DND, 569) without further commentary.

We will return to these two cases of ambiguous word divisions and meanings, but let us first try to reconstruct the communicative situation and the events presented in Tv5 by analyzing those parts of the letter which are undisputed. The document reveals to us the names of three persons and the issue that is at stake:

- Il'ja, who is the addressee of the letter and the owner of a bee-yard. Note that the mention of oaks makes it clear that we are dealing with a lot in the woods with bee-trees (forest beekeeping; cf. Galton 1971, 17-31), not with movable man-made hives.

- Ilijca, who is the sender of the letter and obviously a subordinate of Il'ja; perhaps he is a steward or village elder.

- Šjga, who is 'overwriting the marks on the oaks', obviously not as a simple illegal act, but as someone who claims his rights to the property. After all, in reaction to this, Il'ja is now asked to come over and to 'confirm' his ownership of the bee-yard.

All this information can be gained from the opening and closing sections of the letter, which we will call PART A:

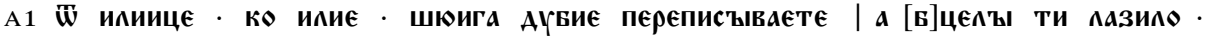 (lines 1-2)}

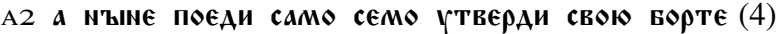

The central section of the letter (PART в) includes the two ambiguous readings discussed above. According to the edition in DND, the communicative function of PART B should be reconstructed as follows:

в1 Азо аүвие Шимаю по своєи мети (2) refers to the measures which Ilijca is taking in respond to the actions of Šujga: 'I am taking away the oaks on my own mark'.

в2 ате [Е]но сотесываете - то мои ауво . (3) points to Ilijca's justification of his measures: 'Let him [even] cut [it] away, it is [still] my oak'.

в3 ваше вортикө окрапоса | перв'ы · (3-4) expresses the assertion of a fact: 'Your bee-yard has been robbed first'.

This interpretation of the meaning of the text raises a number of problematic issues:

- в1: Since we are dealing with non-movable bee-trees, 'take away' (ㅃ̈имаю) can only be interpreted as 'pick out, select; take possession of', in this particular case by putting one's mark of ownership on the oaks (по своєи мети). In view of A1, this would suggest that Ilijca is repossessing the property by putting back his own mark on the oaks which Šjga is 'overwriting' (переписываєте). This, however, seems somehow at odds with the laconic way in which в2 is formulated ('Šujga can do whatever he wants, it's my oak anyhow'). More importantly, Ilijca's own activities are at variance with what he is asking in A2 from Il'ja, namely to come over and get in control of the situation.

- B2: Ilijca's justification of his acts to Il'ja seems superfluous and sounds more like the emotional reaction of an insulted person. Moreover, it is strange that Ilijca, who is standing up for the interests of his superior, uses the words 'it is my oak'. This phrasing would be more natural coming from the owner, Il'ja, not from a subordinate. 
- в3: The significance of the communication that Il'ja's property was robbed first is unclear; what difference would it make to him personally in which order Šujga is robbing other peoples' bee-yards?

These issues cast doubt on the plausibility of the interpretation reflected in the translation in DND. A more plausible scenario of what is communicated in Tv5 has to be found in an alternative treatment of the two problematic instances in line 3 mentioned above: atb [e]nъ and bortnikъ. In our opinion, in both cases the alternative readings that have been proposed by Janin (cf. DND, 569) and Roždestvenskaja (2001), respectively, should be given preference over the interpretation in DND, not only because they can contribute to a better understanding of the communicative function of the letter under discussion, but also on the basis of independent lexical evidence.

The reading aтє $[\boldsymbol{\epsilon}]$ No as atb $[e] n \boldsymbol{s}$ presupposes a combination which is unattested elsewhere in medieval Russian documents. Moreover, the proposed construction would reflect a unique concessive meaning of atь ('пусть [даже]' in DND) and the earliest attestation of the innovative form of the pronoun [jon] 'he' (“в грамоте представлено древнейшее отражение инновационной формы [јон] 'он', , DND, 569). On the other hand, Janin's (cf. DND, 569) alternative reading a тє[c] with the following word сотесываєте, which semantically fits nicely into the context. Although tesbno is an unattested noun (which in the alternative reading would imply a second hapax in the text, next to métb; see Sect. 2.1), the root and its meaning are etymologically transparent (cf. затёс '(tree) mark, incision'), and its word-formation finds a close parallel in пятьно 'brand, branding iron, stain, marking' (attested in N354 from the mid-14th century, as well as in the masculine form пятьнъ in an inscription from Smolensk dated to the end of the 12th or the beginning of the 13th century; cf. Roždestvenskaja 2001, 187f.). ${ }^{3}$

As for the word bortnikz, the meaning of 'bee-yard, apiary' is only mentioned in I. I. Sreznevskij's dictionary ('apiarium', Sreznevskij 1893, 156), next to the meaning of 'beekeeper' ('apiarius'). However, if we take a closer look at the contexts in which the first meaning would apply, it turns out that here, too, the word bortnikz refers to a person, not a property. In SDRJa (I, 330, s.v. бъртьникъ) the word is rightly cited only in the established meaning of 'beekeeper'. ${ }^{4}$

There is another word in Tv5 that is also not attested elsewhere in the meaning proposed in DND, namely okrastisja, which occurs in the perfect tense form окрапосл in line 3 with the supposed passive meaning of 'to be robbed' ('Ваша пасека обокрадена первой' in the translation in DND). Elsewhere on birchbark, in N370 (second half of the 14th century, see DND, 588-590), 'to be robbed' is expressed by the past passive participle of okrasti: өкрадоми · $\mathbf{w}$ мого · ксми 'we have been robbed by him'.

\footnotetext{
${ }^{3}$ The use of two words for what seems to be the same notion, mětb and tesbno, implies a semantic difference, which in view of their context in Tv5 points to mětb referring to the general concept, i.e. any distinctive sign ('mark'), and tesbno referring to the realization of a particular sign made by carving or gouging ('cut-mark').

${ }^{4}$ On the role of the bortnik in medieval Russia, see Galton (1971, 22-24). Incidentally, in his RussianEnglish vocabulary of 1618-1619, Richard James describes a bortnik ("bortnï") as "a kinde of lesser sorte of beare, with a whitish ringe on the necke, verie fierce and so calld because he uses to clime trees for honie [...]-вид медведя меньшей величины, с беловатым кольцом на шее, он очень свиреп, называется так потому, что обычно взбирается на деревья за медом [...]" (Larin 2002, 269). The meaning of 'honeybear' seems to be unattested elsewhere and certainly does not fit in the context of Tv5. However, here too, bortnik is considered an animate noun; perhaps, the connotation 'someone who climbs trees for honey' allowed for the transfer of the meaning of 'beekeeper' to 'honey-bear'.
} 
In other early sources besides Tv5, okrastisja is only found in the well-known work Вопрошание Кирика ('The Questions of Kirik'); here it clearly has a (non-passive) intransitive meaning which can be determined as 'to be guilty of theft' (Sl. XI-XVII vv., XII, 1987, 342), 'to fall into robbery, to be involved in theft' (SDRJa, VI, 113): Аже будет ре(и) татьба велика, а не оуложать ее отаи ..., то не достоить того ставити дьякономь. И оже ли окрадеть(с), а то оуложать отаи, то достоить ('If, he said, it is a major theft, and they do not settle it secretly, then it is not possible to ordain him as a deacon. And if he is guilty of a [minor] theft, and they settle [it] secretly, then it is possible'). Note the juxtaposition of the contrast не оуложать ее отаи 'they do not settle it secretly'-оуложать отаи 'they settle [it] secretly' with the contrast татьба велика 'a major theft'-окрадеть(c), which for okrastisja implies the connotation of a minor offence, committed, so to speak, in an involuntary way, with no real intention of wrongdoing. In our opinion, a similar meaning for okrastisja may be applicable in the context of Tv5: 'to steal, to take away something from somebody thinking by mistake that it belongs to you'.

The proposed interpretation is in agreement with the meaning of Modern Russian verbal word formations containing the prefix $o$ - plus the reflexive particle-sja, which refer to actions that are made by mistake; cf. оговориться 'to make a slip of the tongue', описаться 'to make a slip of the pen', обознаться 'to mistake a person for somebody else'. According to SDRJa (VI, 2000, 138, 150), a clear example in Old Russian is opisatisja/opbsatisja 'to make a slip of the pen' ('Сделать описку'), which is attested in documents from the second half of the 13th and the 14th century.

Taking into consideration the most verifiable interpretation of the phrase a $\mathbf{T E}[\mathbf{c}] \mathbf{N o}$ and of the meanings of bortnik子 and okrastisja, and trying to reconstruct a communicative situation which unites all discourse elements in a coherent way, we propose an alternative reading according to which азо аүвие Жимаю по своеи мети and то мои Аүво. ваше вортикө өкрапоса | первъы have to be treated as renditions of direct speech coming from Šujga:

'From Ilijca to Il'ja. Šujga is overwriting [the marks on] the oaks and has taken out the honey from the hives, [saying:] "I am taking away the oaks on my own mark". He is cutting away the cut-mark, [saying:] "It is my oak. Your beekeeper has fallen into robbery first". And now come here yourself; confirm your [ownership of the] bee-yard. ${ }^{5}$

In this alternative interpretation, the quote "Your beekeeper has fallen into robbery first" has to be interpreted as Šujga's motivation for his actions: he claims that the property rightfully belongs to him because it was stolen from him in the first place by one of Il'ja's beekeepers. The proposed reading makes a clear distinction between the referential structure of the two parts of the letter:

- In PART A, the sender of the letter communicates to the addressee the finding of an undesirable action by an aggressor (A1) and the advice on how to counter it (A2).

- In PART B, the sender elaborates on A1 in terms of a first-hand report of the events, by quoting the reply of the aggressor in a 'live' dialogue taking place in the course of the action: 'What are you doing? - "I am taking away the oaks on my own mark", (в1), 'Why are you doing it? - "It is my oak. Your beekeeper has fallen into robbery first", (B2-3).

\footnotetext{
${ }^{5}$ Russian: ‘От Илийцы к Илье. Шуйга переделывает метки на дубах и вынимал мед из ульев, [говоря]: «Я отбираю дубы по своей метке». А затёс стесывает, [говоря]: «Это мой дуб, ваш бортник первый своровал». Поезжай же теперь сам, утверди [владение] своей бортью.'
} 
If we look at Tv5 from a linear perspective, from the beginning of the letter to the end, the discourse structure resembles that of later čelobitnye (juridical petitions), which typically involve a salutation, a statement of a problem, a narrative exposition, and a proposed course of action (petition) (cf. Volkov 1974, esp. 22-30). In this way, the discourse elements of Tv5 can be arranged as follows:

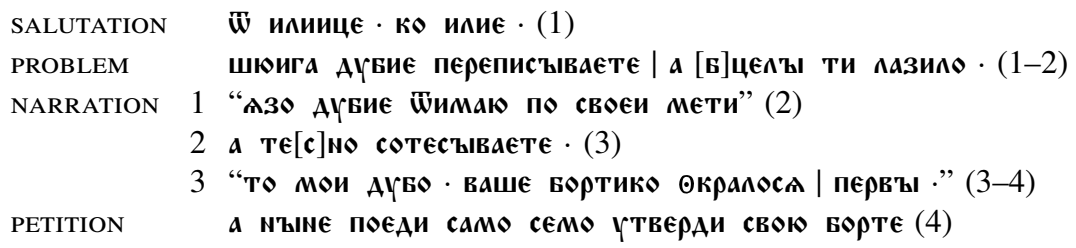

This structure is communicatively appropriate for the hierarchal relationship between sender and addressee in Tv5. Ilijca is reporting to his superior in the most impartial way, distancing himself from direct responsibility: he states the problem and simply cites what he has heard; he does not intervene on his own, but asks his superior to take action.

\subsection{Contextual and lexical parallels}

A clear parallel of the conflict addressed by Ilijca on birchbark can be found in two documents from the recently published 'Court Book' (Судебная книга, 1533-1540) of the Vitebsk governor M. V. Kločko (Voronin et al. 2008, 238f., 255-260). In the trial transcripts no. 136 and 146 from the year 1539, a real-estate lawsuit is recorded which involves the same kind of property violation as attested in Tv5. The arguments brought forward by both parties in the judicial hearings are quoted in a way which is strikingly similar to what we read in Tv5. In one passage, the plaintiffs complain in direct speech about the suspect: '[...] and he ordered to overwrite (perepisati) our other bee-trees, and he cuts off (vytesyvaetb) our old marks, and puts on his own new ones'; also, elsewhere in the transcript, about a specific oak: 'It is our oak (To estъ $d u b ъ$ naš $ъ$ ) and our old mark is on it'. The defendant is quoted as follows: 'It was my rightful oak and I found wild honey (svepet) in it and your mark was not on it (a kleina vašogo na nemъ ne bylo)'; also, elsewhere in the report: 'I am not overwriting your bee-trees (Ja vašyxz [...] bortej ne perepisyvaju) [...] And as for that oak [...] (A što sja dotyčetb togo duba), of which they assume, that it would be their bee-oak, it is my oak and I found wild honey in it and I took that wild honey as my own one rightfully (kotorogo oni menujutb, že by to bylъ ixъ dubъ bortъnyi, ina dubъ moi, a znašolъ esmi v nemъ svepetъ, i ja totъ svepet jako svoi vlasınyi sobe probralъ)'. Note that here too, like in the case of Tv5, the conflict about the oak and the honey is not about an outright theft which might have taken place, but about rightful ownership, about the question whether or not the honey was taken mistakenly by the defendant Mixail for wild honey (kotorogo Mixailo menils svepetom 6 ) and the oak for one that did not belong to anyone. In other words, the defendant is at trial for an action which in Tv5 is described as okrastisja.

Another contextual parallel can be found in the 'Acts of Feudal Landownership and Economy' (Акты феодального землевладения и хозяйства) of the 14th through 16th centuries. In the record of a property ownership conflict from 1584, we read: '[...] they cut away the marks of the monastery (znamjana monastyrbskie stesyvajut) and put on their own, and they take out the bees ( $i$ pčely derut) [...] And the beekeepers from Nagulinskoe, Minja Žoxov and his companions, said that they [...] did not cut away the marks (znamjan ne stesyvajut) and did not put on their own' (Čerepnin 1961, 38). 


\subsection{Absence of tagging direct speech}

It might seem strange that the two instances of direct speech in the proposed interpretation of Tv5 are not introduced by a verbum dicendi or semantically more specific speech-act verb. Usually this is the case in other birchbark letters, where direct speech is most often tagged by the verb molviti 'tell, say'; cf., e.g., N8 'and tell him: "If you want to have the cow..." (АА молови єм8 өжь Хөчьши | көрөвь); N550 "you told Matej: "So much money I have to collect" ' (матьєви еси молви|пь төлико мнћ ємати скота). ${ }^{6}$

However, there is another clear example on birchbark where direct speech also lacks an introductory verbal tag, namely N697 (second half of the 14th century): 'with regard to the fact that you ordered me to take the horse from Putila, he does not give it to me: "I do not owe Kuz'ma anything." '. In the edition, Zaliznjak notes that the introductory tag is left out because 'he does not give' (ме Аасть) by itself already implies Putila's words: (“Отметим, что при прямой речи «не виновать есмь Кузмъ» нет вводящего глагола: он опущен, поскольку не дасть само по себе уже подразумевает некоторую речь Путила" (DND, 576). As a matter of fact, N697 and Tv5 reveal the same communicative pattern: first an unwanted action is reported (Šujga is overwriting the marks on the oaks and is taking out the honey; Putila does not want to give the horse), then the offender's justification for his action is quoted instantaneously. Note that in view of the words 'you ordered me' (есте мнћ вєльли), N697 also seems to be written by a subordinate to his masters.

The fragmentary document N697 features a second instance of direct speech, which in this case is preceded by a verbum dicendi: 'and saying in this way (а рка - такъ): "...". As one of the authors has already pointed out, this illustrates the optional character of a verbal tag introducing direct speech under certain circumstances; the sender can choose to leave out the tag if he thinks that the addressee is able to comprehend the structure of the message on the basis of common ground knowledge of the situational context, cf. Gippius $(2004,191)$ : “[...] имеет место изменение режима интерпретации текста, которое автор или акцентирует при помощи специального индикатора, или же оставляет необозначенным, полагаясь на способность адресата правильно воспринять структуру сообщения исходя из ситуативного контекста”.

Another birchbark letter clearly demonstrates that the sender is conscious of the importance of the communicative transparency of the message when reported speech is introduced. In N962 (first half of the 15th century), the sender, named Oleksej, cites a dialogue about a land conflict: 'Show the letter, on the basis of which you gave it' (положи - гра|моту по уому єси давапъ) and, immediately afterwards, 'The elders ordered me and I gave it' (приказали ми старқшии - и Азъ Аавапъ). Apparently, the writer was not quite sure that the addressee would grasp the communicative structure because in the second instance he inserted superscript tags to indicate the referents: (попъ молвить) 'the

\footnotetext{
${ }^{6}$ Other cases of molviti introducing direct speech are N531, N665, N731, N794, N954, N962, and Staraja Russa 30; see also prefixed vzmolviti 'say' in N531. Other introductory verbs tagging direct speech are: (u)reči (N697, N724), pověstovati (N962), and glagolati (Church Slavonic: N916) 'speak, tell, say'; otvěčati 'answer' (N3, N142), vsprositi 'ask' (N154, N755; see also below, at the end of this section); izvětati 'warn, notify (of misconduct)' (N531; cf. Zaliznjak 1986, 177), zapiratisja 'deny' (N877/572); prislati 'send [i.e. a person or letter to convey something]' (N3; perhaps also N312; cf. Zaliznjak 2000, 98); perhaps also biti čelomb 'petition, state in a petition' (N102; cf. DND, 555). Note that what looks like direct speech in the case of N510, N771, and Staraja Russa 11 is actually part of a specific text-type (cf. Gippius 2004, 223). On the repertory of verbal and other tagging devices for reported speech in Old Russian, see Collins (2001, 5f., 83 [on biti čelomb], 85f., 301).
} 
priest says' over the first quote and ( ${ }^{\text {onecel }) ~ ' O l e k s e j ' ~ o v e r ~ t h e ~ s e c o n d ~ o n e . ~ A s ~ t h e ~ e d i t o r s ~ o f ~}$ the preliminary edition of N962 put it: "Ясно, что вначале автор грамоты (или писец, если автор писал не сам) [...] привел чужие слова без всякого предупреждения о том, кто это говорит. И лишь позднее решил все же это для большей ясности уточнить” (Zaliznjak and Janin 2009, 4f.).

As for examples of direct speech lacking introductory verbal tags outside the birchbark corpus, Zaliznjak (DND, 576) has already pointed out a passage in the First Novgorod Chronicle, where we read under the year 1204: “[...] и съгна ОЦА съ прђстола а самъ $ц^{\mathrm{c}}$ рмъ ста: «ты еси сльпъ, како можеши цр ${ }^{\mathrm{c}}$ тво дьржати, азъ есмь ц'рь»” ('and drove his father off the throne, and became Tsar himself: "You are blind, how can you hold the throne? I am Tsar".').

Finally, it should be noted that other examples, taken from Russian trial transcripts from the 15th century, are discussed by D. E. Collins (2001, 92-103; see also 167-171) under the heading 'free direct speech' (also known as 'zero quotatives' and 'null quotation formulae' in discourse analysis studies). The examples quoted are of a different kind from those observed in Tv5 and N697, in the sense that the reported discourse provides strong and overt cohesion effects which from a communicative point of view easily give the writer the option to leave out specific tags for introducing direct speech without any loss of clarity.

The following fragment (Collins 2001, 93), for instance, contains quotes from a dialogue in which the answer to the preceding question remains without any overt signalling: 'And the judge asked (vsprosil) Stepanko on behalf of all the peasants, "To what good people, longtime residents, among you is this known?" "Among us it is known to Ostaš Panin, and to Fedko"'. As Collins points out, the testimony is presented in a question-and-answer dyadic framework, in which the "represented speaker's identity can generally be inferred from the tag to the preceding question" (ibid.). In fact, this is precisely the case in N154 (early 15th century), where the quoted answer in direct speech is also tagged 'secondarily' by the verb vsprositi 'ask' which introduces the preceding question: 'The people of the law asked (воспросикъ) Omant about Filipp starting the dispute with Ivan Stojko. "I have seen and heard what happened between Filipp and Stojko [...]"' (see DND, 672).

It has not yet been noticed that there is a second case on birchbark which reflects the same dyadic context as N154. In N755 (late 14th century; see DND, 636-638), an eyewitness report in a juridical setting, both question and answer are phrased in direct speech, like in the example quoted above, in which Stepanko is being interrogated by the judge. The letter begins as follows: 'This is all I have to say (толко за мною и сповъ). Oleksej summoned me into the barn because Ostaška was threshing the summer-rye'. Then Oleksej's question to Ostaška is reported: 'Oleksej asked (воспроси) him: "Why are you threshing without our peasants? After all, half the land and part of the crop belong to us"'. The question is followed immediately by Ostaška's reply, without an introductory verbal tag: "My elder, Ivan, ordered me to thresh all of your corn."7

\footnotetext{
${ }^{7}$ By assuming that the last sentence of N755 does not come from Ostaška, but from the anonymous reporter, as is done in the edition (DND, 636f.), the presented discourse would lack communicative coherence with the preceding clause. Also, taking into consideration that the report is not drafted as a letter, with the usual initial salutation to the addressee(s), it remains unclear who the referent is of 'your corn'. The alternative interpretation given in the edition (“хотя и менее вероятно”, DND, 637), according to which Oleksej's words in direct speech would also include the last sentence, is at variance with the obvious assumption that Oleksej himself is a superior (“староста (или управляющий) соседнего села”, DND, 636); cf. 'Oleksej summoned (позвапє) me ...' and 'half ... belong to us (мамъ)' versus 'My elder (старłшћи| мои), Ivan, ordered me (вектиъ ми) ....'
} 
Note that N154 reports about a judicial inquiry (“протокол судебного разбирательства", ibid., 672) and that N755 obviously belongs to the same text-type. The main communicative effect of the use of direct speech in both documents resembles that of medieval Russian trial transcripts: "[...] $\mathrm{D}$ [irect] $\mathrm{s}$ [peech] can create an impression of deferring to the interpreter. [...] By presenting reports as Ds, the scribes relegated as much of the interpretive work as possible to those who were the ratified interpreters, legally empowered to dispense justice" (Collins 2001, 71f.). Although Tv5 is set up in a different way, as a letter from a subordinate to his master, the same strategy of distancing and "self-suppression of the reporter" (ibid., 71) is applied in the narrative part of the text (cf. the end of Sect. 2.2).

\section{Birchbark letter 286 from Novgorod}

\subsection{Novgorod 286 according to the edition in DND}

N286 was found in 1957 during excavations at the Nerev site (Неревский раскоп, усадьба Е, квадрат 1429), located in the medieval quarter known as Nerev End (Неревский конец), on the Sophia Side (Софийская сторона) of the city, north of the Kremlin (Arcixovskij and Borkovskij 1963, 8, 12). The document $(21.0 \times 5.5 \mathrm{~cm})$ is dated stratigraphically to the 1310s-1360s (DND, 595). For additional historical evidence that further pinpoints the date of $\mathrm{N} 286$, see below.

N286 was published in 1963 in the fifth volume of the Academy edition of birchbark documents from Novgorod (Arcixovskij and Borkovskij 1963, 112-114). In later volumes, several corrections in the reading of the text have been proposed (Zaliznjak 1986, 200; 1993, 151; Janin 1986, 242; cf. also Janin 1998, 71-81). The latest edition is by Zaliznjak (DND, 595f.), who also takes into account earlier investigations by other scholars, most notably A. A. Medynceva (Medynceva 1984) and W. Vermeer (Vermeer 1991, 340-349; cf. also idem 1992, 419-423).

In this and the following section, we will not rehearse every detail that has been a matter of discussion in previous literature on N286. We will only address those issues which are relevant for our alternative hypothesis about the communicative structure of the letter and the situational context in which it was written (see Fig. 2).

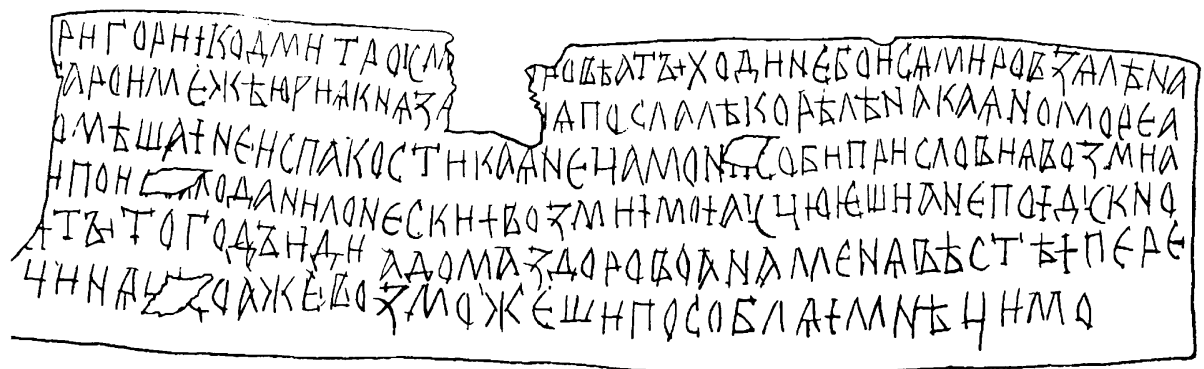

Fig. 2 Drawing of N286 (Arcixovskij and Borkovskij 1963, 113). See http://gramoty.ru for a photograph

Edition (according to DND, 595f.), normalized transcription and translation:

$\begin{array}{llllll}1 & (\boldsymbol{w}) & \text { г)ригори } & \text { кө } & \text { Амитроу } & \mathbf{M}(\mathbf{b} \\ & \text { (ot } & \text { g)rigorii } & \mathrm{k} 6 & \text { dmitru } & \mathrm{m}(\mathrm{y} \\ & \text { From } & \text { Grigorij-GEN } & \text { to } & \text { Dmitr-DAt } & \text { we.PL-NOM }\end{array}$




\begin{tabular}{|c|c|c|}
\hline 3А)[0] рөвћ & $\boldsymbol{a}$ & T'bl \\
\hline zd)[o]rově & $\mathrm{a}$ & ty \\
\hline well-NOM.PL.M & and & you.SG-NOM \\
\hline
\end{tabular}

$\begin{array}{llllll}\text { XөАи } & \text { ne } & \text { вөиса } & \text { мирө } & \text { взАль } & \text { Na } \\ \text { Xodi } & \text { ne } & \text { boisja } & \text { mirъ } & \text { vzjalě } & \text { na } \\ \text { go-IMP.2SG } & \text { not } & \text { fear-IMP.2SG } & \text { peace-ACC.SG } & \text { take-PERF.M.PL } & \text { on }\end{array}$

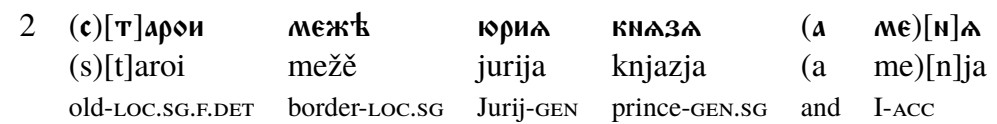

\begin{tabular}{|c|c|c|c|c|c|c|c|}
\hline mocnant & & көрknt & NA & KAANO & \multicolumn{3}{|c|}{ Mope } \\
\hline poslalě & $<\mathrm{k} ?>$ & korělě & na & kajano & \multicolumn{3}{|c|}{ more } \\
\hline send-PERF.M.PL & $<$ to? $>$ & Karelia-DAT.SG & on & Kajan-ACC.SG.N & \multicolumn{3}{|c|}{ sea-ACC.sG } \\
\hline (NE п)omћшаI & NE & испакөсти & ка & Іецам⿻ & กи & сови & \\
\hline (ne p)oměšai & ne & ispaskosti & $\mathrm{k}$ & nьcams & III & sobi & \\
\hline not hinder-IMP.2s & not & harm-IMP.2SG & $\mathrm{Ka}$ & an people-DAT.PL & nor & REFL-I & AT.SG \\
\hline
\end{tabular}

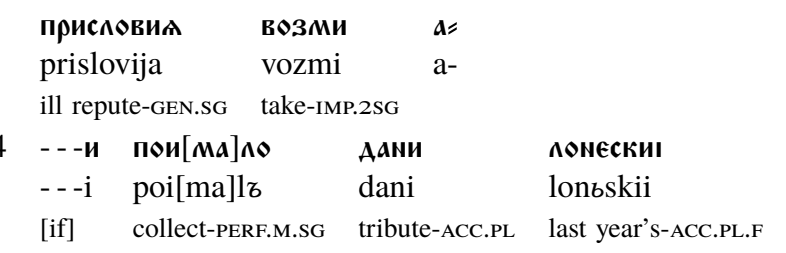

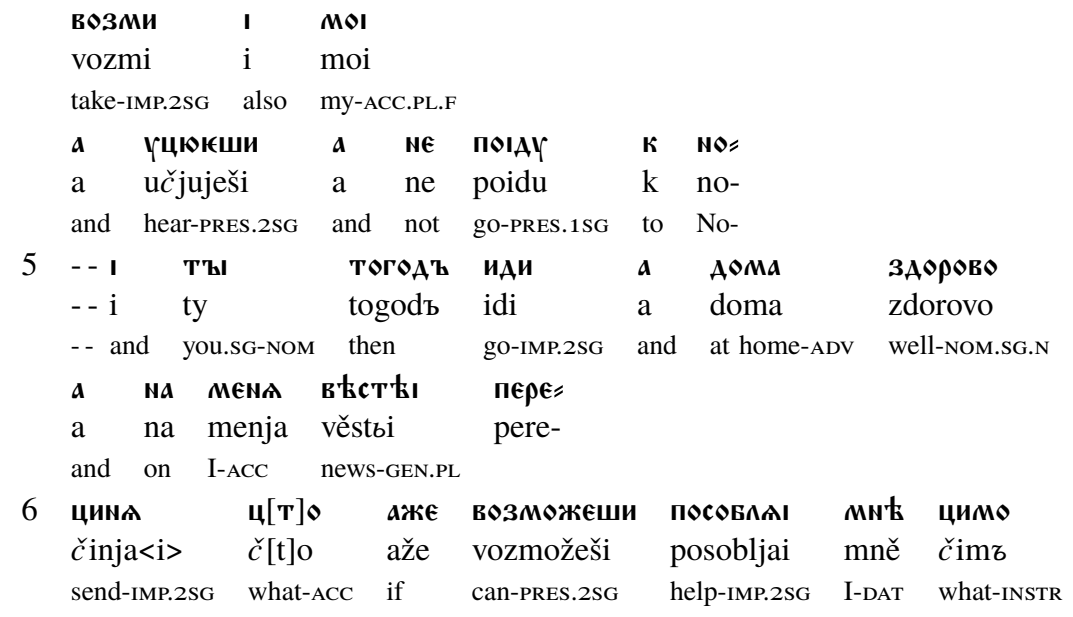

'From Grigorij to Dmitr. We are well. Make your rounds, don't be afraid; they have made peace on the old border of Prince Jurij. And they have sent me to Karelia to the Kajan Sea. And don't hinder, don't do harm to the Kajan people, and don't make a bad name for yourself. If you have collected last year's tribute, take mine also. And if you hear I am not going to No..., then you go. And at home all is well. Send me some news. If you can, help me out with something., 8

\footnotetext{
${ }^{8}$ Russian translation (DND, 596): 'От Григория к Дмитру. [У нас всё в порядке (?)]. А ты ходи (т.е. совершай свои обходы), не бойся-заключили мир по старой границе князя Юрия. [А меня (?)] послали к карелам на Каяно море. А ты смотри не помешай, не напакости каянцам и себе не заполучи худой славы. Если ты уже собрал прошлогоднюю дань, собери и за меня. А узнаешь, [что] я не пойду
} 
Fig. 3 Reconstruction of the conjecture $(\mathbf{a} \mathbf{M E})[\mathbf{N}] \mathbf{A}$ in line 2

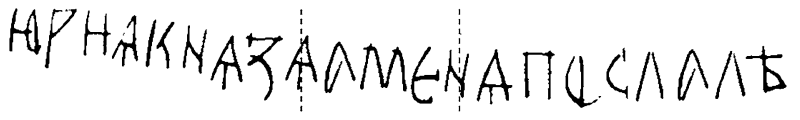

Notes on the conjectures:

- Due to a gap in the middle of the upper side of the birchbark (see Fig. 2), we find two conjectures in the reading in DND: $\mathbf{M}(\mathbf{m} \mathbf{3 A})$ [0]post 'we are well' in line 1, and (a $\mathbf{M E}$ )[N] $\mathbf{A}$ 'and they have sent $m e$ to Karelia' in line 2. The reading 'we are well' was already proposed in the first Academy edition (Arcixovskij and Borkovskij 1963, 113) and is still preferred by Zaliznjak in the latest edition. We will discuss an alternative interpretation (Janin 1998, 81) below, in fn. 10. As for (a ME)[N]A, Zaliznjak (DND, 596) mentions the alternative reading (кымє)[ц] Janin 1986, 242), but admits that the gap leaves little room for four complete letters (“правда, эти буквы уместились бы здесь лишь с некоторым трудом”, DND, 596). A reconstruction of the lacuna, with letters taken from the same document, shows that the length of the gap allows for at most three letters to be inserted (see Fig. 3). This makes the conjecture $(\mathbf{a} \mathbf{M E})[\mathbf{N}] \mathbf{A}$ indeed the most plausible one, especially if we consider that

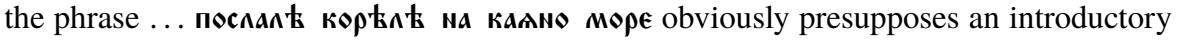
conjunction and an object.

- Since the birchbark was trimmed a little bit too much on the left side, conjectures had also to be made for the beginning of lines 1 through 5. For lines 1 and 2, these are unproblematic. Janin's reconstruction for line 3, (кє п)ом'шшаı 'don't hinder' (Janin $1998,79)$, is quite obvious in view of the syntax and semantics of the clause. For line 4, several conjectures have been proposed, all meaning '(and) if': "На стыке 3-й и 4-й строк явно стояли какие-то слова со значением 'если', 'если же': $а$ (же л)u, $a($ же єс) $u, a(л и ~ m) u$ и т.п. или более короткие $a(\Omega) u, a(u) u$ ” (DND, 596). It is more difficult to reconstruct the beginning of line 5, where two different readings are mentioned in the edition, which are considered equally plausible ("наиболее вероятны", ibid.): $\mathbf{\kappa} \mathbf{N o} \mid(\mathbf{c})[\boldsymbol{\gamma}]$ and $\mathbf{\kappa} \mathbf{N o |}(\mathbf{\kappa})$. For both conjectures, a personal or a place name has been suggested. In the first case, the possibility of the personal (nick)name Nos ('The Nose') can be corroborated by the attestation $\ddot{w}$ юреत к nосу 'from Jurij to The Nose' in N937 (end of the 14th century). In the second case, the underlying lexeme could be Noja, which Vermeer (1992, 423; cf. also Janin 1998, 80) connects with в мои (loc.sg.) 'in Noja' in N278, a document that was written by the same person as N286 (see the next section). Noja has been identified with the Finnish toponym Nuija (Xelimskij 1986, 259). ${ }^{9}$ We will return to the issue of $\boldsymbol{\kappa}$ мо|(c) $[\boldsymbol{\gamma}]$ or $\boldsymbol{\kappa}$ мо|(к) in Sect. 3.3.

Contextual notes:

- The question of the exact historical event to which the sentence 'they have made peace on the old border of Prince Jurij' (миро взалt ма|(c)[т]арои межЫ юриа кмаза, 1-2) refers has been raised several times in the literature (cf. Vermeer 1991, 344f.). There

[к Носу (или: к Ное)], тогда ты иди. А дома всё в порядке. А ко мне кое-что из вестей переправляй. Если сможешь, помогай мне чем-нибудь.'

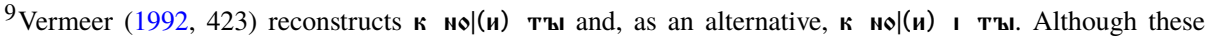
two conjectures are morphologically and syntactically acceptable, in our opinion the graphic information that can be obtained from the photograph most probably points to two letters before the pronoun $\mathbf{T} \mathbf{b}$ : the curled right lower part of a letter that might be $\boldsymbol{\kappa}$ or $\boldsymbol{\psi}$, followed by the letter $\mathbf{~}$ 
is agreement that we are dealing with the border that was settled between Sweden and Novgorod in the Treaty of Nöteborg/Orešek of 1323. The southern part of the border split the Karelian isthmus between the Gulf of Finland and Lake Ladoga in half; more to the northwest, in the Lake Region, several place names were listed as key points in the peace treaty (cf. Sawyer and Sawyer 1993, 67f., including a map of the reconstructed boundaries). In view of the dating of the other documents that were written by the same person Grigorij (see Sect. 3.2), it is likely that the passage points to the renewal of the same treaty in 1351. This would make N286 the earliest document by Grigorij that has survived on birchbark (DND, 595).

- The 'Kajan Sea' (калмо море, 2; cf. калмецамо, 3 'the Kajan people') refers to the Kainuu Sea, an old name for the northernmost part of the Gulf of Bothnia (cf. Julku 1982). It is mentioned in the Russian version of the Treaty of Nöteborg/Orešek (cf. Valk 1949, 67f.; Janin 1991, 88f.) as the last and northernmost point of orientation of the boundary; the territory to the southwest could be exploited by the Swedes, and to the northeast by the Novgorodians (Janin 1998, 75-77; Sawyer and Sawyer 1993, 68).

\subsection{Grigorij's letters and notes on birchbark}

N286 is part of a series of documents written by the same hand and by a person who identifies himself in his letters as Grigorij. In DND (595-602), they are listed under section Г56 Письма и записи Григория. In total, ten of Grigorij's documents over a period of some thirty years have survived: three debt lists (including N403 which also consists of a small Russian-Finnic glossary) and seven (fragments of) letters.

The 'Grigorij block' is closely connected with another series of documentsПереписка Сидора, Семена и Григория-listed under section Г57 of DND (603-607) and containing letters of correspondence between Sidor, Semen, and the same person Grigorij. In this section, Grigorij is probably one of the persons mentioned in N260 ('Instruction from Ostaf'ja to Sidor [...] Take from Grigorij the half-ruble which he promised Sidor'). He is also the addressee of N275/266 ('Instruction from Sidor to Grigorij'), at the end of which the name Dmitr appears. This name may also be reconstructed in fragment N274, which was written by the same hand as N275/266. According to Zaliznjak, it is possible that we are dealing with the same Dmitr who is the addressee of the letter under discussion (DND, 603f.). In view of the fact that in the letter Grigorij writes to Dmitr that 'at home all is well', Zaliznjak leaves room for the conjecture that Dmitr might be Grigorij's brother or another close relative who lives under the same roof ("возможно, это брат Григория (или другой близкий родственник, живущий с ним в одном доме)”, DND, 596).

From Grigorij's own writings and the social network he is part of, we are able to gain a clear picture of his function and activities in Novgorodian society. He must have been working as a tax collector in the northern hinterlands of Novgorod, especially the Karelian region, but he seemed also to be involved in estate and household management. Medynceva (1984) proposes that Grigorij was a тиун боярский, a bailiff or, to put it in modern terms, a 'senior managing assistant' of a major boyar and inhabitant of Nerev End (cf. also DND, 601).

\subsection{Alternative interpretation of N286}

In order to show that the letter as presented in the edition reveals a communicative paradox, we will first divide the text-leaving aside the opening formula-into two referential 
discourse units. In the first unit, Grigorij addresses Dmitr; he gives him a number of advices and instructions, and asks him for some favors. This we shall call PART D, because it is Dmitr who seems to be at the center of the discourse:

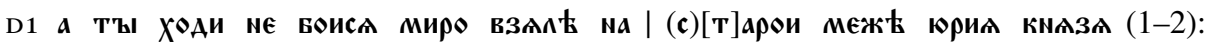
Dmitr is told that he can proceed without fear; the coast is clear on 'the old border of Prince Jurij'. Although the causal relation between the exhortation and the rest of the sentence is not expressed syntactically in an overt way, the communicative relevance of the information about the peace treaty would remain mysterious if we did not assume such a connection.

D2 a| (nе п)омłшаI nе испакости каАнецамо ми сови присловия возми (2-3): Dmitr is obviously advised to operate carefully among the Kajan people and to keep up his reputation.

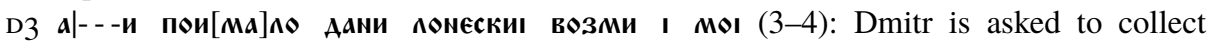
Grigorij's tribute.

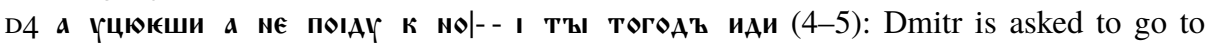
'No...' in the event Grigorij is not going there himself.

D5 a na mena въстkı пере|цина ц[т]• (5-6): Dmitr is asked to send Grigorij 'some news'.

D6 ажє вөзможеши посовлАл мнћ цимо (6); Dmitr is asked to help Grigorij out 'with something'.

In the remaining discourse elements of the letter (PART G), Grigorij informs Dmitr about his own circumstances and about their shared social life. Here, Grigorij is the subject of the discourse:

G1 M(th 3A)[o]post (1): Grigorij and the people who are with him are doing well.

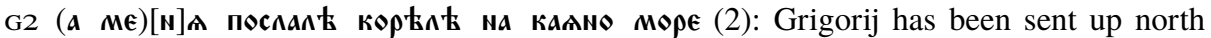
to the remote Kajan region, which in a straight line is some eight hundred kilometers away from Novgorod.

G3 а Аөма ЗАорөвө (5): Grigorij tells Dmitr that everything is fine at home.

Let us first try to establish the location from where Grigorij is writing to Dmitr on the basis of the information he is providing himself (PART G). 'At home' in G3 surely points to the place where Grigorij and Dmitr live: the city of Novgorod. In G2, the semantics in combination with the perfective aspect of the verb poslati 'send' presuppose a directive that was still a topical matter at the moment Grigorij was writing his letter. In view of the knowledge Grigorij has about the situation at home (G3), he might still be in Novgorod while writing to Dmitr about his new assignment and preparing for his long journey. Alternatively, Grigorij might have written the letter on the road, shortly after having left town and still having current information about the circumstances in Novgorod.

Both scenarios have already been proposed for a similar situation which occurs in N723 (mid-12th century): the passage шьль ти єсьмъ күчькъву can be explained either as 'I am on my way to Kučkov' or as 'I am about to go to Kučkov' ("Письмо могло быть написано с дороги; но возможно также, что «я пошел» означает здесь просто 'я сейчас отправляюсь' ", DND, 355). In another case, birchbark letter no. 10 from Toržok (second half of the 12th century; cf. DND, 452), it has been argued by one of the authors (Gippius 2004, 200 and fn. 3) that in view of the situational context the phrase пошьлт петрт | Къ тевє most probably should be interpreted as 'Petr is about to go to you'.

As for N286, it remains inconclusive whether Grigorij wrote the letter in Novgorod or on the road to the Kajan Sea. Taking G1 at face value as a separate message, and 
not assuming that $\mathrm{G} 3$ is merely a paraphrased repetition of $\mathrm{G} 1$, we have to assume that these two utterances presuppose two different referential points. These points may be of a spatial nature, meaning that Grigorij in G1 is referring to the place where he is and where they are doing well, whereas in $\mathrm{G} 3$ he is talking about another place, namely home, where everything is well, too. However, this does not necessarily have to be the case: the two referential points may also be of a merely social nature, in the sense that Grigorij, while still being in Novgorod and writing about his upcoming departure, is referring in G1 to himself and his business partners, and in G3 to his family. Surely, Dmitr must have belonged to the first social group, and obviously also somehow to the second one, because the communicative relevance of $\mathrm{G} 3$ would be difficult to explain otherwise (see Sect. 3.2). ${ }^{10}$

We shall now turn to PART D and first focus on the location of Dmitr at the moment Grigorij is writing his letter. Since Grigorij is reporting to him about the situation 'at home', this location cannot be Novgorod. Against the background of Dmitr's function as a tax collector (see the mention in D3 of danb 'tribute' and also Sect. 3.2 about Dmitr's social environment), the verb ХФАи in D1 should be interpreted as 'make your rounds of collecting tribute' ("совершай свои обходы", as clarified in the translation in DND, 596; cf. fn. 8). This is what he should do on 'the old border of Prince Jurij'. The mention of 'the Kajan people' in D2 seems to be a further spatial specification of the borderline (see Sect. 3.1). Since Хण्A in D1 does not imply a movement in the direction of, but a movement among the Kajan people, we have to assume that at the moment the letter was composed, Dmitr must already have been in the same region where Grigorij was supposed to work in the (near) future, i.e. the Kajan Sea.

However, it is only with great difficulty that we can connect the remaining information provided in PART D in a communicatively coherent way with the reconstruction of the different locations of Grigorij and Dmitr, as well as with the clear assumption that they will be working in the same region:

- It is unlikely that Grigorij's request about the tribute ('take mine also') in D3 is related to collecting taxes in the Kajan region, because Grigorij is being sent there himself. It is also hard to accept that the request refers to a different area: on the one hand, Dmitr should do his work among the Kajan people; on the other, he is being asked to collect Grigorij's taxes somewhere else?

- A similar problematic question arises in the case of D4: again, Dmitr is asked to go somewhere or to someone ('No...'), in addition to proceed in the Kajan region.

- The lexical semantics and the imperfective aspect of the verbs in the two last requests in D5 ('send [перє|цима] me some news') and D6 ('help [посовлАI] me out with something') do not give the impression that Grigorij and Dmitr will meet each other soon in the Kajan region.

In principle, such an impression might be brought factually into accord with the information which can be deduced from D3 and D4, as well as the rest of the letter. This would mean that

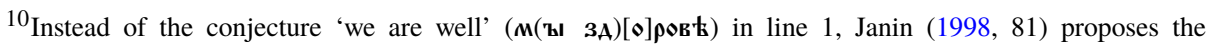

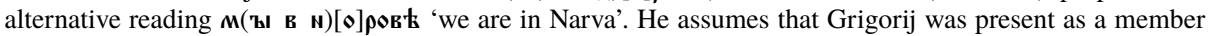
of the Novgorod delegation at the 1351 renewal of the Treaty of Nöteborg/Orešek in Jur'ev (Tartu) and was then heading for the Karelian isthmus. On his way, in Narva, he must have written his letter to Dmitr, who was somewhere near the Karelian isthmus and waiting for a sign that the coast was clear. Although

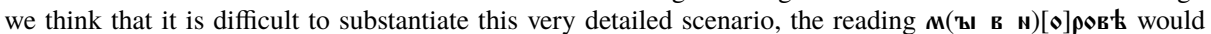
fit in our more general assumption that at the moment Grigorij wrote his letter, he was either in Novgorod or had recently left town to go up north to Karelia; he might have traveled through Narva, which is two hundred kilometers away from Novgorod. On the basis of the concrete evidence we have at hand, we prefer to stick in our analysis to the conjecture as given in the latest edition.
} 
Grigorij is writing that he has been sent to the Kajan Sea, that Dmitr can already go ahead with his work there too, but before doing so, he should first help Grigorij out with a couple of things and also keep him posted. However, from a communicative point of view, the way in which Grigorij composes his letter does not make much sense: right after the apparently most important instruction, that he operate diplomatically among the Kajan people (D2), he immediately, without any clarifying introductory words, switches over to a series of requests (D3-D6), which all seem to undermine or contradict the principal assignment. Thus, there seems to be an apparent contradiction between the discourse elements D3-D6 and $\mathrm{D} 2$.

In our opinion, this paradox in the reconstruction of the course of events and the way in which they are communicated can be solved best if we assume that one specific discourse element has a different referential perspective which has not been recognized before: the utterance in D2 does not refer to Dmitr, but to Grigorij himself: '... And they have sent me to Karelia to the Kajan Sea: “don't hinder, don't do harm to the Kajan people, and don't make a bad name for yourself". ...'.

The proposed alternative reading gives the letter a clear communicative structure:

- After a brief general update about his own situation (G1), Grigorij informs Dmitr that it is safe for him to proceed with his work as a tax collector (D1).

- Then Grigorij reports to Dmitr about the instructions he has been given himself, to go 'to Karelia to the Kajan Sea' (G2) and to make sure that he does not 'hinder ... the Kajan people ...' (D2).

- As a consequence of these new instructions, Grigorij is not able to fulfill the tasks he was supposed to do and asks Dmitr to help him out, i.e., to collect his tribute (D3) and to go to 'No...' if he hears that he himself cannot make it there (D4).

- In the remainder of the letter, it seems that Grigorij addresses Dmitr more as a relative, a friend, than as a business partner: he writes that everything is fine 'at home' (G3), asks Dmitr to keep him informed by sending him 'some news' (D5) and to help him wherever he can (D6).

- Thus, whereas the first part of the letter, starting with 'we are well' (G1), deals with business matters, the closing section, beginning in a similar way with 'And at home all is well' (G3), seems to be of a more personal nature. ${ }^{11}$

In the alternative reading, Dmitr is not the one who is operating in the remote area of the Kajan people. Nevertheless, he is definitely collecting tribute in the Karelian region, somewhere 'on the old border of Prince Jurij' (D1). We propose that, whereas Grigorij is leaving for or is already on his way to the northernmost part of the border, Dmitr is working in the more southern region along the border. The toponyms mentioned in other writings of Grigorij (N278, N130 and N403) indicate that this was the main area-the Karelian isthmus-where he and his partners must have been working as tax collectors: “Лайдикола, Курола, Кюлолакша, Сандалакша, Погия (Погицы) отыскиваются на Карельском перешейке, в Задней Кореле, в Богородицком Кирьяжском погосте. Следовательно, именно этот участок был подведомствен данникам Григорию, Дмитру и Науму” (Janin 1998, 81).

Against this background, the conjecture $\mathbf{\kappa} \mathbf{~} \mathbf{} \mathbf{} \mid(\mathbf{\kappa})$ 'to Noja', reflecting the Finnish toponym Nuija (see Sect. 3.1), would fit well in our proposed reconstruction of N286.

\footnotetext{
${ }^{11}$ From the photograph and drawing (Fig. 2) we get the impression that there is a graphic division between these two parts: there is a small gap between them, which is atypical in comparison with the rest of the letter, and the second part starts on a somewhat lower level on the same fifth line.
} 
Although Nuija seems to be a rather common place name (“довольно распространенный”, Xelimskij 1986, 259), it is mentioned together with Laidikola and Kurola in N278 (в мои 'in Noja'), which makes it plausible that we are dealing with a place in the southern region of Karelia. It is this region where we assume Dmitr has to operate and also has to take over Grigorij's tasks, as mentioned in D3 and D4. Both utterances may in fact express a single message, meaning that D4 is a further spatial specification of D3: "If you have collected last year's tribute, take mine also; that is, if you hear I am not going to No[ja], then you go'. This would imply that Grigorij is leaving open the possibility that he will still be able to do his job in southern Karelia, perhaps after having fulfilled his duties among the Kajan people; Dmitr will be given further notice (а үцюкши 'if you hear') if Grigorij's itinerary does not work out as planned.

How did it come that N286 was eventually, six hundred years later, recovered in the city of Novgorod? Of course, there is always the default explanation that the letter was not sent. However, its content gives a clear motivation for returning the letter as written proof of the assignments that were given in it. This procedure applies to more cases of birchbark letters with instructions, which were clearly sent out of the city, but have been excavated in Novgorod (cf. Schaeken this volume). What first comes to mind is Grigorij's tribute which Dmitr is supposed to collect; he actually did so, and the revenues were brought back to Novgorod (by himself or by a messenger), including the letter as proof of Grigorij's authorization.

Since we lack sufficient information about the contextual situation of Grigorij's letter, we cannot provide a watertight reconstruction in full detail of the course of events. However, in our opinion, the basic assumption that the passage 'don't hinder, don't do harm to the Kajan people, and don't make a bad name for yourself' refers to Grigorij and not to Dmitr, is the only way to create a plausible general scenario of what Grigorij is communicating to Dmitr.

\subsection{Directive or necessitive use of the imperative?}

In the previous section we have put the discourse element 'don't hinder, don't do harm to the Kajan people, and don't make a bad name for yourself' between (double) quotation marks. This may suggest that we are dealing with yet a new case on birchbark, in addition to Tv5, of direct speech which lacks an introductory verbal tag (cf. Sects. 2.2 and 2.4): Grigorij is quoting the words of his superiors who are sending him to the Kajan Sea. This would mean that the imperatives 'don't hinder' ((ме п)омкшаı), 'don't do harm' (кє испакости), and 'don't make a bad name for yourself' (ми сови присловия вөзми) have to be interpreted as straightforward directives. From a communicative point of view, however, this is odd: what would be the relevance of Dmitr knowing the reported speaker's deictic reference points? If it were in another context, e.g., in a text-type of a (quasi-)juridical kind, where a conflict is at the center of discussion, be it in court or in reports which may possibly end up as evidence in a trial, we could understand the communicative relevance of using direct speech (cf. Sect. 2.4).

In our opinion, it is more plausible that in the case of N286 the discourse element 'don't hinder, don't do harm to the Kajan people, and don't make a bad name for yourself' has a special emotive value. The three imperatives are not of a directive nature, but reflect the 'necessitive meaning' (долженствовательное значение/наклонение, cf. Švedova 1974) of the imperative, which is a semantic transposition of the directive use and draws attention to an unjust situation which has somehow arisen. The speaker voices his negative attitude to the action that is imposed on him: "The imperative is used to express that 
the subject is forced or obligated to do the imperative action. This imperative use can be paraphrased, depending on the context, with modal predicates that express necessity such as dolzhen, nado ('must', 'have to')" (Fortuin 2000, 56). The stylistically colored necessitive imperative is well-known in colloquial modern Russian; cf., e.g., Все ушли, a я сиди дома и работай 'Everybody has gone out, but I have to stay at home and work' (Švedova 1974, 107). The following two examples are taken from E. Fortuin's discussion of the necessitive combined with second person subjects which refer to the speaker himself: Несусветная жара, а ты сиди и занимайся как миленький 'Тhe heat is unbearable, but you [i.e. 'I'] have to sit and study like a sweet child' (Fortuin 2000, 121); И за порядком в квартире следи, и субботники проводи и с обязательствами по дворам ходи,-думаете, легко одной-то? 'I have to keep the apartment tidy, and I have to [do] voluntary work and I have to fulfill my obligations in various places, do you think, that is easy for a woman all alone?' (ibid., 111).

In his research on the meaning of the necessitive imperative in modern Russian, Fortuin has already drawn attention to an example in the birchbark corpus: "Интересно отметить, что подобные предложения уже употреблялись в XIV веке ([DND, 588f.] дает пример без подлежащего из новгородского текста)" (Fortejn 2008, 11, fn. 8). The reference concerns N370 (see also Sect. 2.2), which is a letter 'from all the peasants' complaining to Jurij and Maksim about their steward: 'What have you given us for a steward? He doesn't stand up for us. He's selling us out, and we've been robbed by him. And you

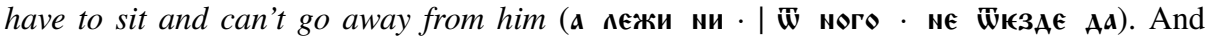
we have perished because of this. If he is to stay, we don't have the strength to stay; so give us a peaceable man'. The sentence is highlighted in the edition (“Очень интересна фраза а лежи [...]-свойственным народному языку использованием императивов для передачи (с неодобрением) чужого требования [...]”, DND, 589) and translated into modern Russian retaining the second singular imperatives (пєжи and мє ФюзАє): 'А сиди и не смей от него отъехать!'.

The stylistically colored necessitive imperative is appropriate in the context of N370, where the peasants in strong words call on Jurij and Maksim to rid them of their steward. In a similarly emotional way, in N286 Grigorij expresses to Dmitr his dissatisfaction about the fact that he has now been sent to the remote Kajan Sea, instead of carrying out other duties he had planned or anticipated. Against the background of the close relationship which is presumed between Grigorij and Dmitr, it is communicatively not strange that Grigorij wants to share his feelings about the new assignment in an expressive way; he phrases his thoughts as if Dmitr should imagine himself how he would feel if he had to fulfill such an onerous task.

In sum, we propose the following alternative reading of N286:

'From Grigorij to Dmitr. We are well. Make your rounds, don't be afraid; they have made peace on the old border of Prince Jurij. And they have sent me to Karelia to the Kajan Sea. [Can you imagine:] You [i.e. 'I'] shouldn't hinder, shouldn't do harm to the Kajan people, and shouldn't make a bad name for yourself! If you have collected last year's tribute, take mine also. And if you hear I am not going to Noja, then you go. And at home all is well. Send me some news. If you can, help me out with something. ${ }^{12}$

\footnotetext{
${ }^{12}$ Russian: 'От Григория к Дмитру. У нас все в порядке. А ты ходи, не бойся-заключили мир по старой границе князя Юрия. А меня послали к карелам на Каяно море. [Ты только представь: ведь нужно] не помешать, не навредить каянцам и себе не заполучить худой славы! Если ты уже собрал прошлогоднюю дань, собери и за меня. А узнаешь, что я не пойду к Ное, тогда ты иди. А дома все в порядке. А ко мне кое-что из вестей переправляй. Если сможешь, помогай мне чем-нибудь.'
} 


\section{Conclusion}

The two case studies we have presented in this paper show that it is fruitful to examine birchbark documents carefully with respect to their internal discourse cohesion and their external communicative purposes. Such a pragmaphilological approach provides new and more plausible interpretations of the linguistic form in which the documents are put on birchbark.

We have argued that from a coherent discourse point of view, it has to be assumed that parts of Tv5 and N286 have a referential perspective which differs from previous interpretations of both letters. In the case of Tv5, the proposed reanalysis reflects instances of direct speech without introductory verbal tags. These instances are strategically appropriate in a discordant setting which resembles a juridical procedure. Our investigation in Tv5 also throws new light on the semantics of individual lexemes; the existence of the hapax tesbno, and the meaning of bortnik子 and okrastisja.

In the case of $\mathrm{N} 286$, our reanalysis of the referential perspectives of the different discourse elements at first sight points to another instance of direct speech lacking an introductory verbal tag. We have tried to show that on closer inspection the discourse element under discussion displays a different semantic load. Here, we are dealing with instances of second person imperatives which are used in a necessitive meaning in a discourse which reflects an emotionally colored comment of the sender of the letter on an undesirable instruction that has been given to him. This would make N286 the earliest Old Russian document in which the necessitive imperative is attested.

Open Access This article is distributed under the terms of the Creative Commons Attribution Noncommercial License which permits any noncommercial use, distribution, and reproduction in any medium, provided the original author(s) and source are credited.

\section{References}

Anpilogov, G. N. (1964). Bortnye znamena kak istoričeskij istočnik. Sovetskaja arxeologija, 4, 151-169.

Arcixovskij, A. V., \& Borkovskij, V. I. (1963). Novgorodskie gramoty na bereste. Iz raskopok 1956-1957 gg. Moskva.

Čerepnin, L. V. (1961). Akty feodal'nogo zemlevladenija i xozjajstva. Čast' tret'ja. Moskva.

Collins, D. E. (2001). Reanimated voices. Speech reporting in a historical-pragmatic perspective (Pragmatics \& Beyond. New Series, 85). Amsterdam.

DND: Zaliznjak, A. A. (2004). Drevnenovgorodskij dialekt. Vtoroe izdanie, pererabotannoe s učetom materiala naxodok 1995-2003 gg. Moskva.

Fortejn, E. (2008). Polisemija imperativa v russkom jazyke. Voprosy jazykoznanija, 1, 3-23.

Fortuin, E. L. J. (2000). Polysemy or monosemy: interpretation of the imperative and dative-infinitive construction in Russian. Ph.D. dissertation. Amsterdam. http://www.hum2.leidenuniv.nl/pdf/S\&R/ fortuin_polysemy_and_monosemy_dissertation.pdf. Accessed June 12, 2010.

Galton, D. (1971). Survey of a thousand years of beekeeping in Russia. London.

Gippius, A. A. (2004). K pragmatike i kommunikativnoj organizacii berestjanyx gramot. In V. L. Janin, A. A. Zaliznjak \& A. A. Gippius (Eds.), Novgorodskie gramoty na bereste. Iz raskopok 1997-2000 gg. Tom XI (pp. 183-232). Moskva.

Janin, V. L. (1986). Popravki i zamečanija k čtenijam berestjanyx gramot. In Novgorodskie gramoty na bereste (iz raskopok 1977-1983 gg.). Kommentarii $i$ slovoukazatel' $k$ berestjanym gramotam (iz raskopok 1951-1983 gg.) (pp. 220-251). Moskva.

Janin, V. L. (1991). Novgorodskie akty XII-XV vv. Xronologičeskij kommentarij. Moskva.

Janin, V. L. (1998). Ja poslal tebe berestu ... Izdanie 3-e, ispravlennoe i dopolnennoe novymi naxodkami. Moskva.

Janin, V. L., \& Zaliznjak, A. A. (2000). Novgorodskie gramoty na bereste (iz raskopok 1990-1996 gg.). Paleografija berestjanyx gramot $i$ ix vnestratigrafičeskoe datirovanie. Moskva. 
Julku, K. (1982). Tuohikirjeen 286 ajoitus [The date of birchbark letter no. 286]. Faravid, 6, 117-120.

Kotkova, N. S. (1963). Nazvanija russkix bortnyx znamen-istoriko-lingvističeskij istočnik. In S. I. Kotkov \& O. A. Knjazevskaja (Eds.), Issledovanija po lingvističeskomu istočnikovedeniju (pp. 120-133). Moskva.

Larin, B. A. (2002). Tri inostrannyx istočnika po razgovornoj reči moskovskoj Rusi XVI-XVII vekov. Sankt Peterburg.

Medynceva, A. A. (1984). Pis'ma Grigorija-tiuna bojarskogo (po materialam berestjanyx gramot). In I. P. Rusanova (Ed.), Kul'tura i iskusstvo srednevekovogo goroda (pp. 53-75). Moskva.

Roždestvenskaja, T. V. (2001). Tverskie berestjanye gramoty Nr. 2-5. In V. A. Lapšin (Ed.), Tverskoj kreml': kompleksnoe arxeologičeskoe istočnikovedenie (po materialam raskopa Tverskoj kreml'-11, 1993-1997) (pp. 185-189). Sankt-Peterburg.

Sawyer, B., \& Sawyer, P. (1993). Medieval Scandinavia. From conversion to reformation, circa 800-1500. Minneapolis, London.

Schaeken, J. (this volume) 'Don't shoot the messenger': a pragmaphilological approach to birchbark letter 497 from Novgorod'. Russian Linguistics, 35(1).

SDRJa: Slovar' drevnerusskogo jazyka (XI-XIV vv.). Tom I-. 1988-. Moskva.

S1. XI-XVII vv.: Slovar' russkogo jazyka XI-XVII vv. Tom I-. 1975-. Moskva.

Sreznevskij, I. I. (1893). Materialy dlja slovarja drevne-russkago jazyka po pis'mennym pamjatnikam. Tom $1(A-K)$. Sanktpeterburg.

Švedova, N. Ju. (1974). O dolženstvovatel'nom naklonenii. In G. A. Zolotova (Ed.), Sintaksis i norma (pp. 107-121). Moskva.

Valk, S. N. (Ed.) (1949). Gramoty Velikogo Novgoroda i Pskova. Moskva, Leningrad.

Vermeer, W. (1991). Aspects of the oldest Finnic poem and some related texts (Novgorod birchbark documents 292, 56 and 403). In A. A. Barentsen, B. M. Groen \& R. Sprenger (Eds.), Studies in West Slavic and Baltic linguistics (Studies in Slavic and General Linguistics, 16) (pp. 315-359). Amsterdam.

Vermeer, W. (1992). Evfim'ja, Maskim and others: critical notes on Novgorod birchbark documents. In A. A. Barentsen, B. M. Groen \& R. Sprenger (Eds.), Studies in Russian linguistics (Studies in Slavic and General Linguistics, 17) (pp. 383-434). Amsterdam.

Volkov, S. S. (1974). Leksika russkix čelobitnyx XVII veka. Formuljar, tradicionnye ètiketnye $i$ stilevye sredstva. Leningrad.

Voronin, V. A. et al. (2008). Sudebnaja kniga vitebskogo voevody, gospodarskogo maršalka, volkovyskogo i oboleckogo deržavicy M. V. Kločko. 1533-1540. Moskva.

Xelimskij, E. A. (1986). O pribaltijsko-finskom jazykovom materiale v novgorodskix berestjanyx gramotax. In V. L. Janin \& A. A. Zaliznjak (Eds.), Novgorodskie gramoty na bereste (iz raskopok 1977-1983 gg.). Kommentarii i slovoukazatel' $k$ berestjanym gramotam (iz, raskopok 1951-1983 gg.) (pp. 252-259). Moskva.

Zaliznjak, A. A. (1986). Novgorodskie berestjanye gramoty s lingvističeskoj točki zrenija. In V. L. Janin \& A. A. Zaliznjak, Novgorodskie gramoty na bereste (iz raskopok 1977-1983 gg.). Kommentarii $i$ slovoukazatel' $k$ berestjanym gramotam (iz raskopok 1951-1983 gg.) (pp. 89-219). Moskva.

Zaliznjak, A. A. (1993). Popravki i zamečanija k čteniju ranee opublikovannyx berestjanyx gramot. In V. L. Janin \& A. A. Zaliznjak, Novgorodskie gramoty na bereste. Iz raskopok 1984-1989 $\mathrm{gg}$. (pp. 123-180). Moskva.

Zaliznjak, A. A. (2000). Popravki i zamečanija k čteniju ranee opublikovannyx berestjanyx gramot. In V. L. Janin \& A. A. Zaliznjak, Novgorodskie gramoty na bereste (iz raskopok 1990-1996 gg.). Paleografija berestjanyx gramot $i$ ix vnestratigrafičeskoe datirovanie (pp. 82-122). Moskva.

Zaliznjak, A. A., \& Janin, V. L. (2009). Berestjanye gramoty iz novgorodskix raskopok 2008 g. Voprosy jazykoznanija, 4, 3-12. 